\title{
PVDCラテックスからのナノ炭素とその焼結体 の形態観察
}

\section{Morphology on a nanocarbon prepared from PVDC latex and resulting sintered materials}

\section{野村忠範 **, 島村喜代司**, 宮下憲和**}

Tadanori Nomura**, Kiyoshi Shimamura** and Norikazu Miyashita**

\begin{abstract}
PVDC carbons are interested as a candidate of active carbon for EDLC electrodes or a storage material for methane or hydrogen, because of its has high bulk density and narrow distribution of nanopores. A nanocarbon was prepared from PVDC copolymer latex by alkaline-dehydrochlorination and subsequent pyrolysis. The latex in solids of $50 \%$ based on weight is commercially available. The aggregates of partially dehdrochlorinated latex in alkaline aqueous solution are was easily redispersed, filtered and rinsed. SEM images showed that the shape and the size of the particles of latex are substantially maintained ; the nanoparticles in the latex, the precursors and the sintered material had almost same shape and size. TEM images showed that nanocarbons with hollow-like (core-shell) or onion-like structure are exhibited. The shell phase of the hollow-like carbon seemed to have high density. The onion-like carbon was considered to be partially graphitized.
\end{abstract}

KEYWORDS : Nanocarbon, PVDC latex, Hollow-like spherical carbon, Onion-like spherical carbon, Sintered material

\section{1. 緒 言}

ポリ塩化ビニリデン (Polyvinylidene Chloride : PVDC) の生 産能力は, 全世界で約 13 万トン/年であり, 全プラスチック生産量 の0.2\%あまりである (Table 1)。工業的製造法として, 水を分散 媒とする濁重合法 (Suspension Polymerization Technology) また は乳化重合法 (Emulsion Polymerization Technology) が採用され ている。下記の用途に応用されるための押し出し加工適性やコ ーティング適性から, 塩化ビニリデン (VDC) 単独を重合したホ モポリマーではなく, 塩化ビニルやアクリル系モノマーとのコポ
リマー (Copolymer, 以下PVDCはコポリマーを指す) が工業的 に製造されている(Table 2, Table 3)。

懸濁重合または乳化重合されたCopolymerは, それぞれ, 脱水, 乾燥, あるいは塩析, 脱水, 乾燥された後, 押し出し加工され, 繊維, フィルムになる。また, 乳化重合された水分散体Copolymer（ラテ ックス) はそのままで, 基材にコーティングされたり, 塩析, 脱水, 乾燥されたもの (ソルブル・レジン) を有機溶剤に溶解させ, 基材に コーティングされて, 実用に供せられている。主用途は優れた酸 素あるいは水蒸気バリアー性を活かした食品包装材への応用で ある。

Table 1 Major manufacturers, polymerization processes, products and estimated capacity of PVDC.

\begin{tabular}{|c|c|c|c|c|}
\hline Area & Producers & Process & Products & Capacity, tons/y \\
\hline $\mathrm{EU}$ & Solvin & Emulsion Polyxn. & Latex, Soluble Resin, Extrusion Polymer & 25,000 \\
\hline \multirow{5}{*}{ USA } & \multirow{2}{*}{ Dow } & Suspension Polyxn. & Extrusion Polymer & \multirow{2}{*}{20,000} \\
\hline & & Emulsion Polyxn. & Soluble Resin & \\
\hline & W\&Grace & Emulsion Polyxn. & Latex & 8,000 \\
\hline & \multirow{2}{*}{$\begin{array}{l}\text { Rhom\&Haas } \\
\text { BF Goodrich }\end{array}$} & Emulsion Polyxn. & Latex & 5,000 \\
\hline & & Emulsion Polyxn. & Latex & 2,000 \\
\hline \multirow{4}{*}{ Japan } & \multirow{2}{*}{ Asahi } & Suspension Polyxn. & Extrusion Polymer & \multirow{2}{*}{40,000} \\
\hline & & Emulsion Polyxn. & Latex, Soluble Resin & \\
\hline & \multirow{2}{*}{ Kureha } & Suspension Polyxn. & Extrusion Polymer & \multirow{2}{*}{30,000} \\
\hline & & Emulsion Polyxn. & Latex & \\
\hline & & & Tota & 130,000 \\
\hline
\end{tabular}

* Corresponding Author, E-mail: tm_nomura@nifty.com

* (有)TMO-野村 : = 882-0865 宮崎県延岡市鶴ヶ丘1-20-22

* Technologies Management Office-Nomura : 1-20-22 Tsurugaoka, Nobeoka, Miyazaki 882-0865, Japan

**旭化成ケミカルズ(株): テ 882-0847 宮崎県延岡市旭町7-4319

** ASAHI KASEl Chemicals Co. : 7-4319 Asahimachi, Nobeoka, Miyazaki 882-0847, Japan 
Table 2 PVDC products, fabrication technologies ans major applications.

\begin{tabular}{|c|c|c|c|}
\hline Polymerization & PVDC Products & Fabrication Technologies & Applications \\
\hline \multirow{3}{*}{ Emulsion Polymerization } & Latex & Latex Coatings & Coatings for Food Barrier Packagings \\
\cline { 2 - 4 } & Soluble Resin & Solvent Coatings & Ibid \\
\cline { 3 - 4 } & \multirow{3}{*}{ Extrusion Polymer } & Inflation Process & Films for Food Barrier Packagings \\
\cline { 3 - 4 } & & Molton Spinning & Doll's Hair, Filters and Shoes Insole \\
\cline { 3 - 4 } & & Inflation Process & $\begin{array}{c}\text { House Hold Wrap and } \\
\text { Films for Food Barrier Packagings }\end{array}$ \\
\hline
\end{tabular}

Table 3 PVDC molecular composition and solid stracture.

\begin{tabular}{|c|c|}
\hline Composition & Stracture \\
\hline VDC $>85$ molar\% & Crystalline Polymer \\
\hline VDC $<15$ molar\% & Amorphous Polymer \\
\hline
\end{tabular}

PVDC Carbon (PVDC炭素, Saran Char)としては, 過去に, R. A. WesslingによるPVDC炭素に関する研究総括1がある。

また, 大谷杉郎らの塩素化炭化水素からの炭素に関する一連の 試み2)がある。前者はPVDCの炭素化機構, PVDC炭素の性質や 応用を広範に総括してあり, 後者は低温度で形成される炭素 (Low Temperature Pyrolytic GraphiteまたはLow Temperature Pyrolytic Carbon) の新しい製法を提案している。

PVDC炭素は高いミクロ細孔（極端に,マクロ細孔ゃメソ細孔 が少ない) を有し, 密度の高い, 非晶性ドメインにランダムに配置 された黒鉛微結晶をもつ炭素 (Monolithic Carbon) である。分子 篩効果, 高い伝導性, 磁気的特性や力学的特性が検討されている が,いまだ応用には結びついてない。塩素化炭化水素からの炭素 も黒鉛面との界面接着性の改良効果があるとの報告もある。

PVDC 炭素の応用として, 最近になって, 水系電気一重層キャパ シ夕 (Electric Double Layer Capacitor ; EDLC) 用高密度活性炭 電極材料 ${ }^{3)}$, 高いガス (メタン4) あるいは水素5) 吸蔵容量をもつ 高密度活性炭として, PVDC炭素が注目されてきている。KOH を用いた従来の賦活法により，ホモPVDCを化学的に賦活した PVDC 炭素6) あるいはアセト酢酸イットリウムを新規な賦活剤 としてPoly (VDC/MA) を賦活して,メソポーラス炭素7)とし, 有 機系EDLCへの応用もある。

また, Quin 58) は, 標準的な水蒸気や炭酸ガス賦活法あるいは低 温酸化と高温窒素サイクリック賦活法を用いて, ミクロ細孔容積 を増やす試みをしている。

一方, Wojtowiczら 9) は, 改良したサイクリック賦活法を用い て, ボイドの $40 \%$ を削減して, メソ細孔を増やすことなくミクロ 細孔容積を増やす提案をしている。これらは選択的にミクロ細 孔容積を増やす方法で, 化学エッチングといえる。

特異的な応用として, 半導体業界で使用されるドーピングガス, 例えば水素化セレン, 水素化リンや水素化ケイ素などの毒性ガス 吸蔵体 10) が提案されている。

PVDC ラテックスからのナノ炭素として, 第1段階で, PVDC テックスをアルカリ水溶液と有機溶剤を組み合わせて脱塩酸し, 第2段階で, 流動層で熱的に脱塩酸させて, ラテックス粒子径を 保持した微粒子炭を得る試み11)がある。
しかし，工業的に製造される其重合系ラテックスからのPVDC 炭素やその形態学に関する研究はない。

この解説では, 特に, アルカリ水溶液で局部的に脱塩酸処理し やすい共重合系ラテックスを単独のアルカリ水溶液で局部的に 脱塩酸処理し, その後の熱炭素化させた特異なナノ炭素粒子の構 造の形態観察を示す。アルカリ水溶液で部分的に脱塩酸させた 炭素前駆体を不活性雲囲気あるいは真空中で, 熱的に, 実質的に 完全脱塩酸させて得られたナノ炭素のTEM やSEM イメージを紹 介する。また, 非晶質PVDC炭素のTEMイメージも紹介する。

また, アルカリ水溶液単独で脱塩酸させたナノ炭素前駆体の凝 集シートを加圧して作製したグリーンシートを, 引き続き, 加圧 下で熱的に脱塭酸させて作製した焼結体，その表而のPd-Pt 金属 粒子や2つの複合焼結体のSEM イメージを紹介する。

比較のため, 懸濁重合品の低温熱炭素化前駆体とその炭素化物 や高温炭素化品のSEM イメージや備長炭のTEM イメージも示す。

\section{2. 実 験}

\section{1 試料}

水分散系PVDC 共重合体の代表としてのPVDC 樹脂は乳化剂 を使用して重合する乳化 (Emulsion) 重合法, 懸濁剂を使用して 重合する懸濁（Suspension）重合法または乳化剂と懸濁剂を併用 して重合する乳化・懸濁水分散 (Espension) 重合法により準備 できる。特に, 乳化 (Emulsion) 重合法と乳化・眯濁水分散 (Espension) 重合法は粒子径が小さく, 均一で, 化学炭素化工程で の脱塩酸反応が均一に進行して好ましい。一方, 懸濁 (Suspension) 重合法で得られる粒子径は大きくても，その内部構造において，粒子 径がナノサイズと小さく,均一な粒子の凝集体である (Fig.1, Fig.2)。

\subsubsection{PVDCの重合}

\section{[乳化重合]}

PVDCの乳化重合過程の概念図を Fig.3に示す。水中のVDC モノマー油滴から乳化剂ミセル中に拡散してきたモノマーはナノ サイズで, 水溶性重合性開始剤により重合が進み, PVDCラテッ クスとなる。このラテックスもナノサイズを保持する。

工業的には, $10 \mathrm{~nm}$ から $200 \mathrm{~nm}$ 程度のラテックスが製造できる。 具体的重合法の一例を以下に例示する。ガラスライニングを施 した耐圧反応機中に水 85 部, アルキルスルフォン酸ソーダ (バイ エル社, 商品名「ワロラートU」) 0.15 部および過硫酸ソーダ 0.1 部を仕込み, 脱気した後, 内容物の温度を $55^{\circ} \mathrm{Cに}$ に保った。

これとは別の容器に塩化ビニリデン (VDC) 98 部, アクリロニ トリル (AN) 1.5 部,メタアクリル酸 (MAA) 0.5 部を計量混合し 


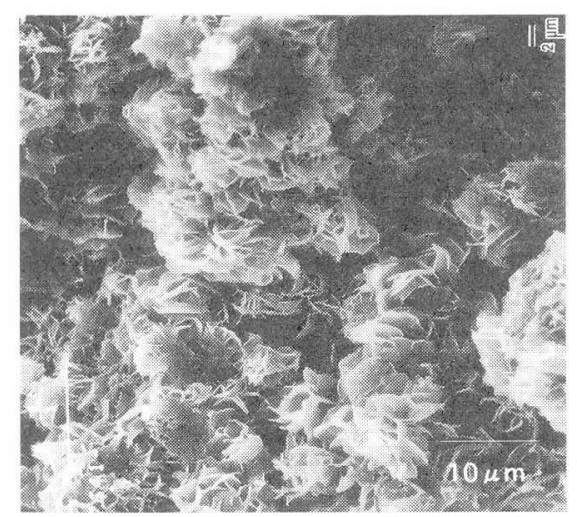

Fig.1 SEM image of carbon precursors after low temperature treatment on suspention polymerized PVDC.

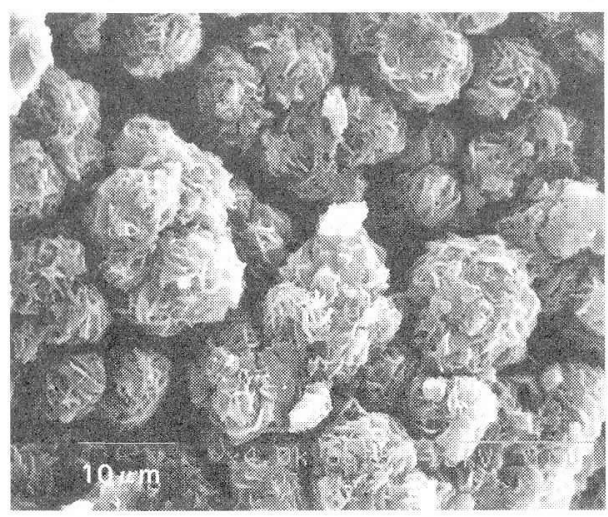

Fig.2 SEM image of carbon from low temperature treated suspention polymerized PVDC.

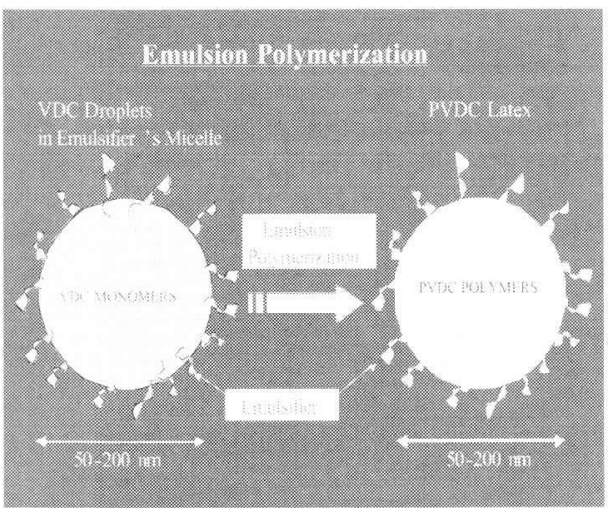

Fig.3 General concept PVDC emulsion polymerization proces.

てモノマー混合物を作製した。

前記耐左反応機中にモノマー混合物のうち10部孝・括添加し, 覺拌下, 反応機の内圧が降下するまで重合した。続いて, 残りの モノマー混合物 90 部在 12 時間にわたって連続的に定量添加し た。业行して,アルキルスルフォン酸ソーダ1部も10時間にわた って連続的に定量添玑した。得られたラテックスは50ー150nm申 の粒径がSEM観察される(Fig.4)。

ナノサイズのPVDCラテックスの製法として例えば, 1997 年 (株シーエムシー出版「高分子微粒子の最近技術と用途展開」記 載の複合粒子, 例えば,ソリッド, コアーシェル構造, ザクロ状構

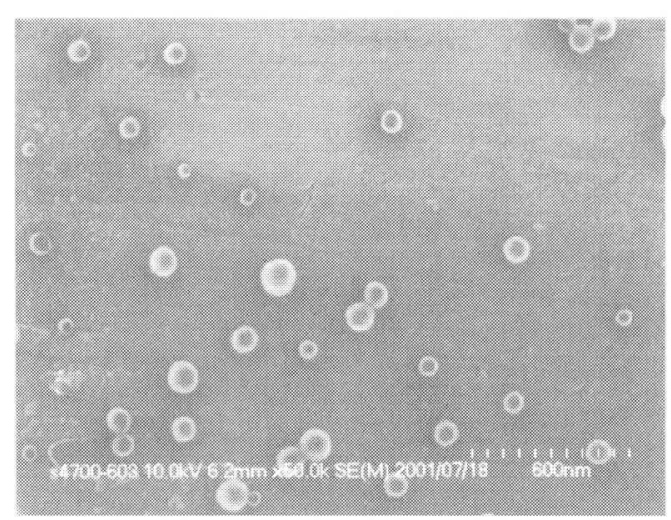

Fig.4 SEM image of PVDC latex.

造やコンペイ糖構造などの各種複合粒子がPVDCラテックスに 伈用だる。

[懸濁重合]

ガラスライニングを施した耐压反応機中に水 280 部, ヒドロキ シプロピルメチルセルロース（信越化学工業㧣製：墑品名「メト ローズ $65 \mathrm{SH}-400 」$ (粘度 $380 \mathrm{mPa} \cdot \mathrm{s}$, 表面張) $49 \times 10^{-3} \mathrm{~N} / \mathrm{m}$ (0.2\%固形分, $\left.25^{\circ} \mathrm{C}\right) 0.5$ 部, ジイソプロピルカーボネート 0.2 部 を仕迟み, 脱気した後, 内容物を常温に保った。こ机とは別の容 器にVDC90部, 塩化ビニル (VC) 10 部計量混合してモ)マー混 合物老作製した。

前䛉耐厈反応機中にモノマー混合物を一括添加し, 常温のまま 30 分㩭拌: 在続けた後, 内容物の温度在 $20,40,60,80^{\circ} \mathrm{C}$ と早温さ せながら重合させ、内压が十分に降下寸るまで反応を進行させた。 未反応モノマー在減导せながらスチームストリッピング回収し た。降温後ボリマーのスラリーを遠心分離㙨で脱水した後, 熱風 乾燥機で乾燥品在得た。これによりポリマー䊉子サイズが $100 \mu \mathrm{m}$ から $200 \mu \mathrm{m}$ である, 実質的に球状樹脂が得られた。

[エスペンション重合]

照濁重命に使用さ机る懸濁剂と乳化重合に使用さ机る乳化剂 を併用して重合するう法を総称して,エスペンション重合という。 超音波やホモジナイザーなどのノ学的攪拌も併用できる。ガラ スライニングを施した耐庄反心機中に水280部, ヒドロキシプロ ピルメチルセルロース(信越化学丁業㫼製：墑品名「メトローズ $650 \mathrm{SH}-400 」$, 粘度 $380 \mathrm{mPa} \cdot \mathrm{s})$, 表面張力 $49 \times 10^{-3} \mathrm{~N} / \mathrm{m}(0.2 \%$ 固形分, $\left.25^{\circ} \mathrm{C}\right) 0.5$ 部, ジイソプロピルカーボネート 0.2 部老仕込 み, 脱父した㣪, 内容物在常温に保った。これとは別の容器に VDC100部とナトリウム・ジアルキルスルホコハク酸塩 (花王株) 製：阅品名「ペレックスTR」, 純分 70 \%) 2 部老計量混合してモノ マー混合物を作製した。前記耐压反応機中にモノマー混合物を 一括添加し, 常温のまま30 分攪找老続けた後, 内容物の温度を上 昇させ, $40^{\circ} \mathrm{C}$ に保ち, 内压が十分に降下するまで反心を進行させた。

これにより一次粒子径が100－200nmで，これらがザクロ状凝 集した粒了・歼が $1 \mu$ から $20 \mu \mathrm{m}$ である䒠質的に球状凝集体が 得ら机た。

\section{1 .2 ナノ炭素前駆体の作製}

前記 [乳化重合]により得られたラテックス 10 部老 120 C $\mathrm{C}, 50 \%$ 


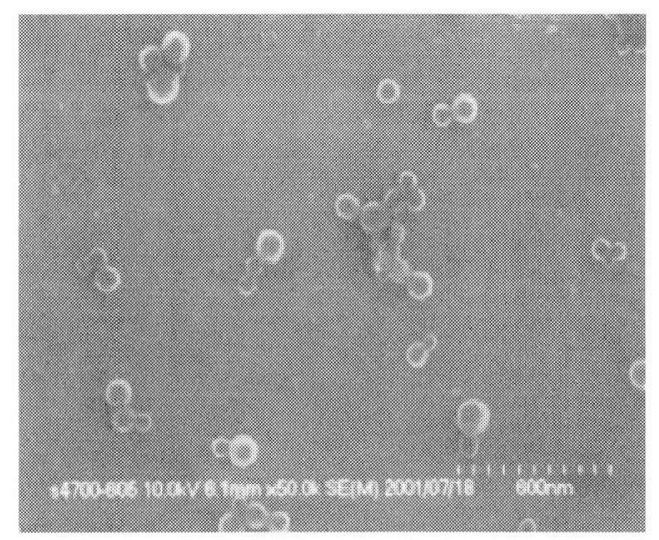

Fig.5 SEM image carbon precursor after alkaline teatment on PVDC latex.

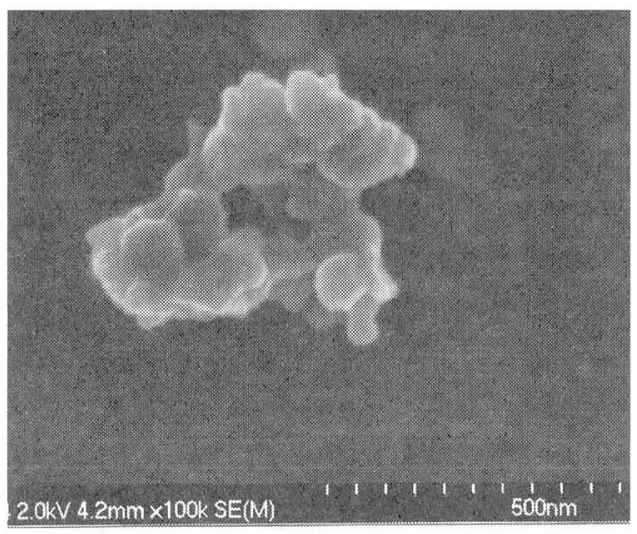

Fig.6 SEM Image of carbon precursor aggregates after alkaline teatment on PVDC latex.

$\mathrm{KOH}$ 水 20 部で 8 時間接触し, 脱塩酸させた後, 洗浄万過水の $\mathrm{pH}$ が8以下になるまで, 万過と洗浄老繰り返して, 炭秦前駆体老得 た。再分散させた炭素前駆体と凝集体のSEM觀察をそれぞれ，

Fig.5とFig.6に亦す。

さらに, ポリアクリルニトリルやポリメタアクリルニトリルか らのラテックスや石油や石炭ピッチ, フェノール樹脂やフルフラ 一ル樹脂のラテックスとPVDC炭素前駆体とを配合した複合炭 素前駆体も有用である。

\section{1 .3 ナノ炭素の作製}

\subsubsection{1 窒素気流中での作製}

炭素前駆体の凝集体を電気加熱式環状炉に仕込み, $\mathrm{N}_{2}$ 雲囲気

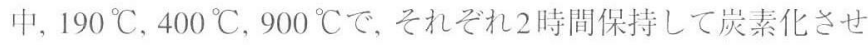
た。凝集炭素と1個の炭素をそれぞれ, Fig.7 と Fig.8に示す。

\subsubsection{2 真空中での作製}

炭素前駆体の凝集体存石英ガラス中に封入し, 真空下で封止し, 電気炉に保持した。 $5^{\circ} \mathrm{C} /$ 分の昇温速度で, $520^{\circ} \mathrm{C}$ にるまで加 熱し, その温度で120時間保持し炭素化させた。1個の粒子のTEM 観察をFig.9に示京。

\section{2 焼結体の作製}

\subsection{1 ナノ炭素焼結体}

$50 \%$ 水分を含有するウエットケーキを压縮成型機で, 直径 $20 \mathrm{~mm} \phi$, 厚み $2 \mathrm{~mm}$ に予備プレス成形し,グリーンシートを得た。

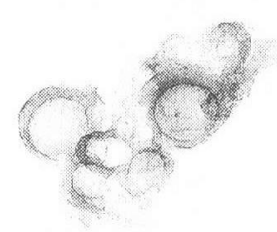

$\underline{100 \mathrm{~nm}}$

Fig.7 TEM image of PVDC nanocarbon aggregates.

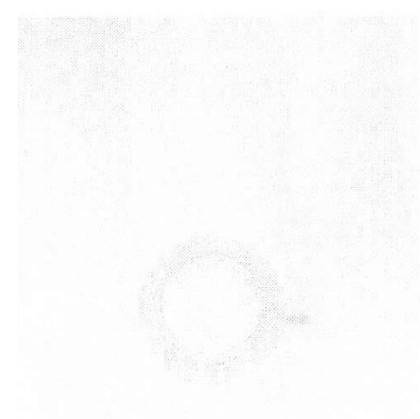

$50 \mathrm{~nm}$

Fig.8 TEM image of a PVDC nanocarbon.

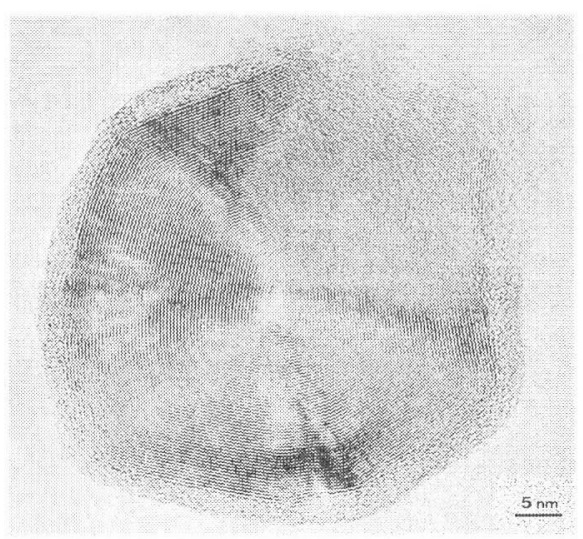

Fig.9 TEM image of a partially graphited PVDC nanocarbon.

このグリーンシート表面のSEM 観察老Fig.10 に示す。窣素父流 中で, 炭素化焼結した炭素ディスクの直径は $13 \mathrm{~mm}$, 厚みは $1 \mathrm{~mm}$ であった。このディスク表面のSEM観察をFig.11に示す。

\subsubsection{Pd-Pt蒸着ナノ炭素複合焼結体}

2.2.1のナノ炭素焼結体の表面に蒸着したPd-Pt苲着ナノ炭素複 合炭素焼結体老得た。この焼結体表面のSEM 観察老Fig.12に示す。 


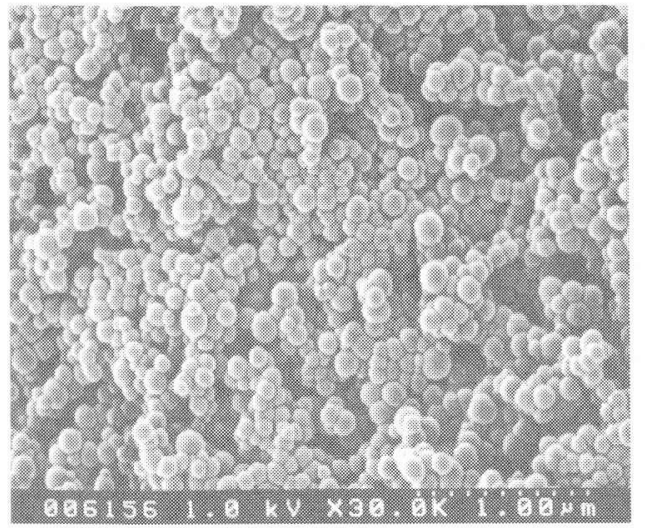

Fig.10 SEM image of green sheet from carbon precursor aggregates after alkaline teatment.

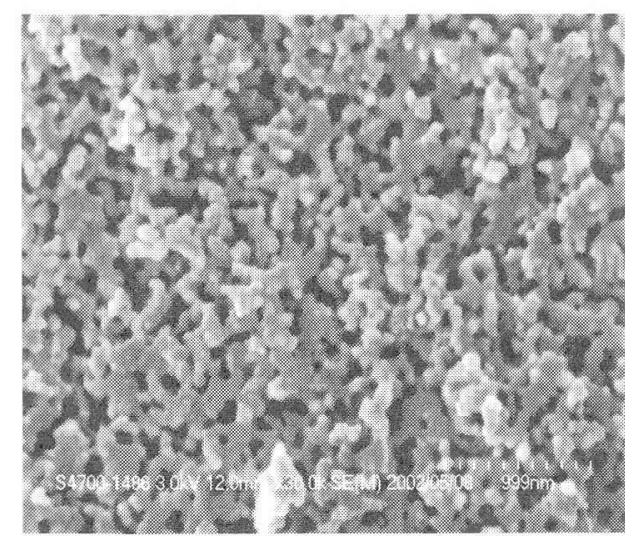

Fig.11 SEM image of sintered nanocarbon sheet.

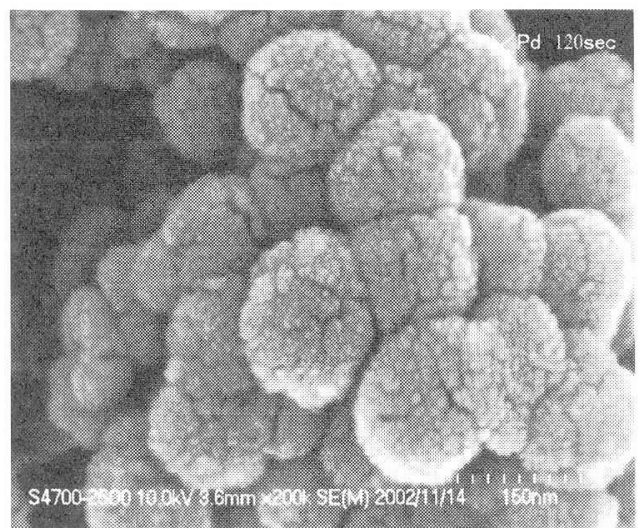

Fig.12 SEM image of sintered carbon nanocarbon material deposited with Pd-Pt.

\subsection{3 ナノ炭素とVGCF 複合焼結体 (Composite Material-1)}

2.2.1のグリーンシートを作製するとき, 10 \% V GCF (Vapor Grown Carbon Fiber) 老十）炭素前駆体の水分散液に添加し, 複合 ウエットケーキをプレスで脱水しながら，门盤状に成形した。室 温中で, 一珀夜, 風乾した後, 2.1.3.1の炭素化条件で炭素化し, 焼 結体とした。ナノ炭素とVGCF複合焼結体表面のSEM 観察を Fig.13に示市。

2.2.4 懸濁重合炭素とナノ炭素複合焼結体 (Composite Material-2) 2.2.3のナノ炭素とVGCF複合焼結体のVGCFの代わりに, 懸

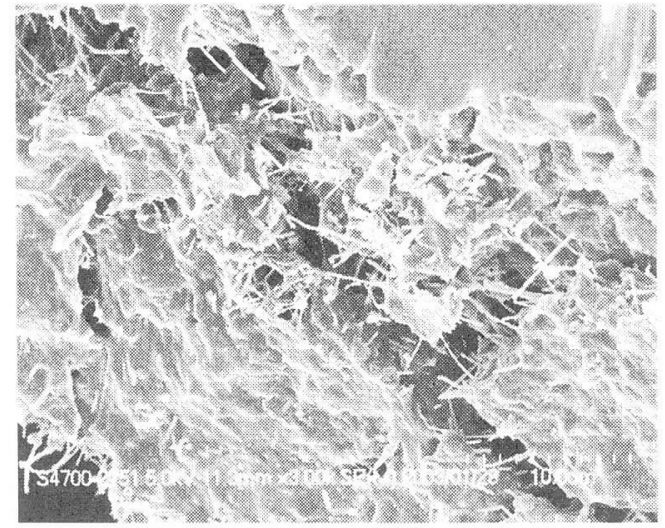

Fig.13 SEM image of sintered carbon nanocarbon composite material-1.

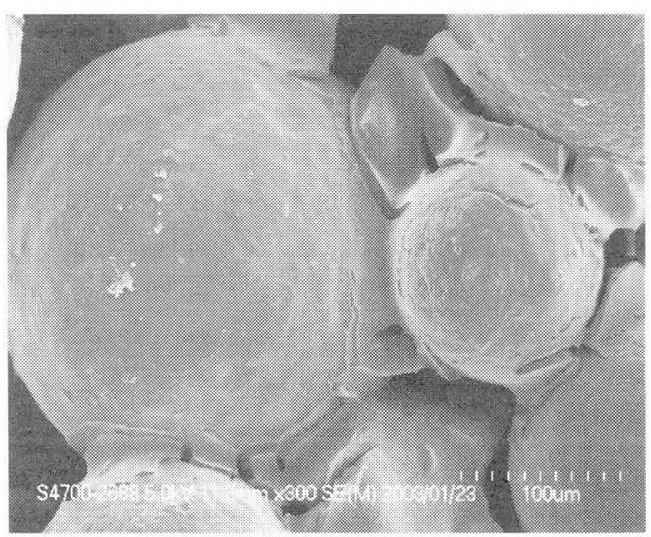

Fig.14 SEM image of sintered carbon nanocarbon composite material-2.

濁重合炭素前駆体を添加し, 2.2 .3 と同じ条件でグリーンシート とした2.1.3.1の炭素化条件で炭素化し, 焼結体とした。䀣濁重合 炭素と十ノ炭素複合焼結体体表面のSEM観察存Fig.14に示す。

\subsection{SEM と TEM 観察方法}

\subsection{1 走査型電子顕微鏡 (SEM) 観察}

原料ラテックスとナノ炭素前駆体は100 倍希釈し, 霧吹きでアル ミ䈌の上に噴霧し,ドライキャビネット内で乾燥させた。アルミ䇴 を $1 \mathrm{~cm}$ 们に切り出し，カーボン雨面テープを用いて SEM 観察用 アルミ製試料台に固定した後, 試料にPt-Pdコーティングまたは Os コーティングを行い, 使用装置FE-SEMS 4700 (日立製作所株) 製) , 1.0 - 30kVで観察した。

\subsection{2 透過型電子顕微鏡 (TEM) 観察}

ナノ炭素をメ夕ノール中に, 超音波分散させ, カーボン支持膜 を張った銅グリッド上に滴下・乾燥して検体とした。使用装置 はJEM-4000FX (日本電子(秼)) 加速電压350kVで観察した。

また, 真空中で炭素化したナノ炭素のTEM 観察は, 30 万倍の倍 率で格子像を撮影し, 得られたネガを10倍に引き伸ばして印画紙 に焼付け, 300 万倍のTEM観察とした（Fig.9）。

2.3.3 マイクロビーム電子線回折（Micro Beam Electron Diffraction : MBED)

実体顕微鏡下に㧍いて, エ夕ノール中に分散した試料微粉末を カーボン支持膜付き 200 - A 銅メッシュで拾い上げてTEM試料 


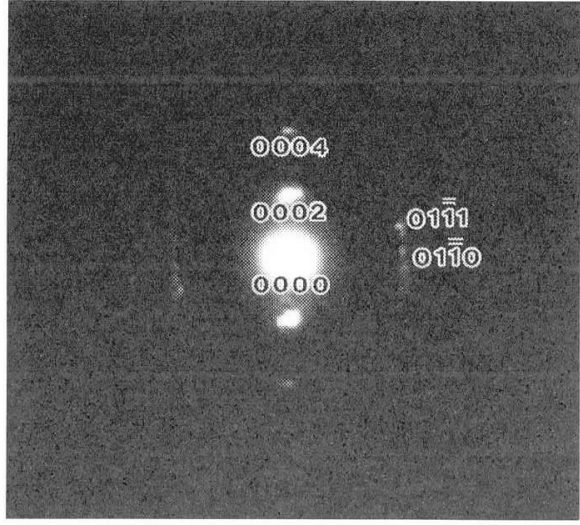

Fig.15 MBED image of graphited portion of a PVDC nanocarbon.

とした。FE-TEM (HF2000, 日立製作所制)を用いて, ビーム直徫 2nmdでMBED観察（カメラ長 $0.4 \mathrm{~m}$ ) を実施し, 得られたネガを 5 倍に引き伸ばして印画紙に焼付け, 電子線回折パターンとした

グラファイトは空間群P6-3/mmc ( $2 \mathrm{H}$ 構造, 格了定数 $\mathrm{a}=2.461 \AA$. $\mathrm{c}=6.708 \AA)$ として, 回折スポットの指数付けをした (Fig.15)。

\section{3. 観察結果と考察}

\section{1 観察結果}

以下に, SEM, TEM とMBED 観察結果の概要を示す。

1.SEM観察によれば, 原料ラテックス,ナノ炭素前駆体とナノ岑素 は,ほぼ同じ形状と粒子径分布在保持されている。

2. TEM観察によれば, ナノ炭素内部は数個の立した電子密度の 低いドメインと電子密度の高いシェル層の複層炭素が観察さ 机る。電子密度の低いコアー層, 電子密度の高いシェル層の 2 層構造をもつ複層炭素である。

また， $900{ }^{\circ} \mathrm{C}$ で焼結した炭素塊はナノ炭素同上が焼結した構造 である。

3.SEM観察によれば，グリーンシートの炭素集合状態が保持さ れた焼結体を形成する。

また, Pd-Pt蒸着材が焼結体老形成するナノ炭素粒了表面に毢栗 状に固着している。

4.TEM観察によれば, 低温, 真空下で炭素化させて得られたナ， 炭素は表面が非晶で, 内部が結晶様の構造が見られる (Fig.9)。 MBED 観察によ机ば, 内部が部分グラファイト化したナノ岑素 である(Fig.15)。

5. SEM 観察によれば, Pd-Pt蒸着ナノ炭素複合焼絬体はナノ炭素 表面に, 逃栗状のPd-Ptが形成している（Fig.12）。

6.SEM観察によれば,VGCF圭添加した複合焼結体はナノ炭素 塊同士を補強するように, 亀裂のある十ノ炭素塊間にブリッジを 形成している(Fig.13)。

7.SEM観察によれば, 眯濁PVDC炭素前駆体を添加した複合焼結体 はナノ炭素塊か懸濁PVDC炭素粒子間に密着している (Fig.14)。

8. SEM 観察によれば, 懸濁PVDC 炭素前駆体とその炭素体は队 部構造が実質的に保持されている。ナノサイズの炭素からな る燐片状か観察される（Fig.1, Fig.2）。

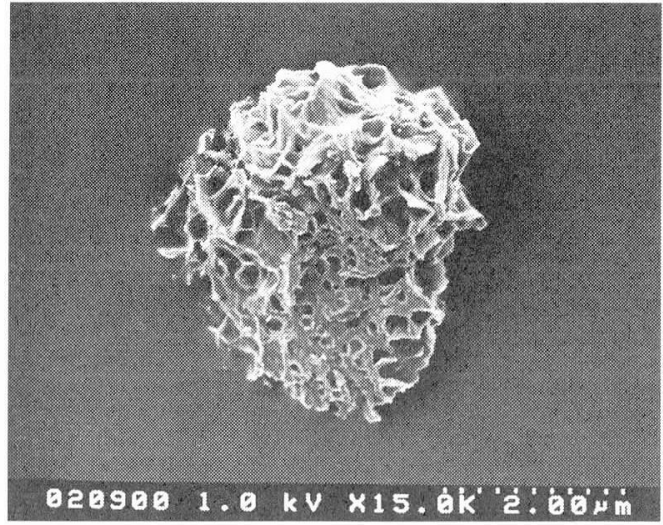

Fig.16 SEM image of carbon foam by conventional pyrolysis of suspention polymerized PVDC.

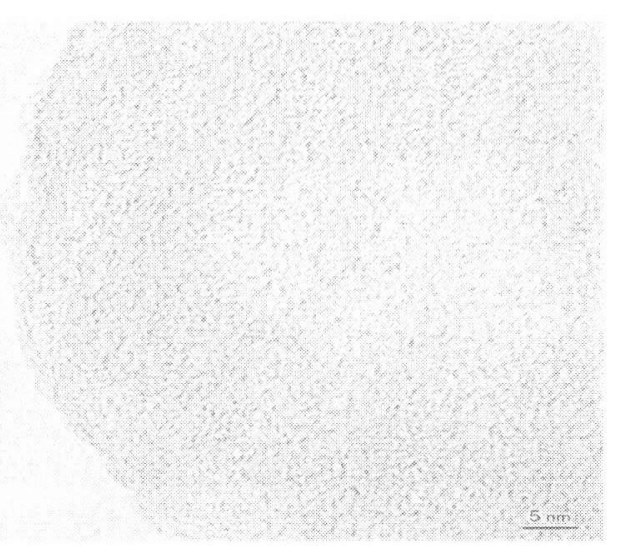

Fig.17 TEM image of amorphous PVDC nanocarbon.

一方，前駆体を経ずに炭素化させたPVDC炭素はポン菓子状の 発泡体が得られる (Fig.16)

\section{2 考察}

\section{2 .1 結果の考察}

不活性ガス中で炭素化して得られるPVDC炭素は䒠質的に非 晶性（Fig.17）で, 市販の備長炭（Fig.18）より,緩やかな構造を もっている活性炭と考えられる。その炭素化過程プロセスを Fig.19に示す。また, ラテックスから得られる炭素前駆体在炭素化 して得られるPVDC炭素は実質的に非晶性で, 電子密度の低いコ アー層, 電子密度の高いシェル層の2 層構造存もつ複層炭素であ る。その炭素化過程プロセスをFig.20に示守。

一方, 真空中で炭素化して得られるPVDC炭素は比較的低温で 炭素化が進み, 十ノ炭素は表面が非晶で, 内部が不完全グラファ イト結晶様の構造が見られる。その炭素化機構は不明であるが, アルカリ脱塩酸で周定化された殸は非晶性炭素となり，無垢の PVDC 核はPVDCの熱分解で発牛导る塩酸が触媒的作用し,グラ ファイト様構造になると考えている。

\section{2 .2 加工性}

炭素焼結体老作製するとき, 水分散性在活かし, 単独でグリーン シートにしたり，補強材で補強した複合グリーンシートができる。 また, 接着性を活かし, 異種の金属や炭素と複合化も容易である。 


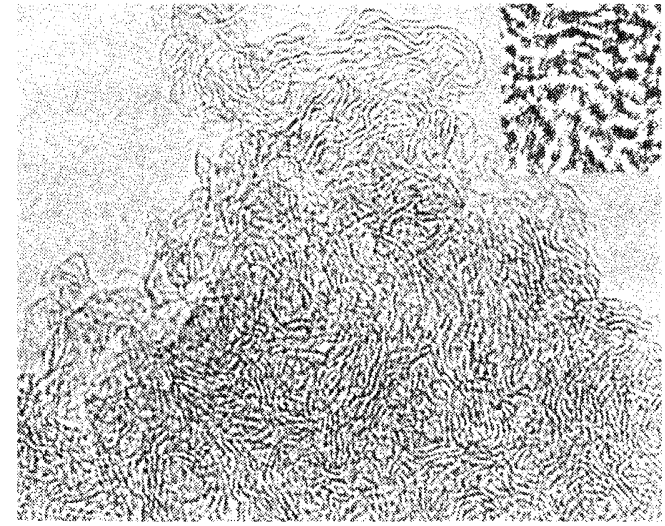

Fig.18 TEM image of char coal from Japanese chest nut.

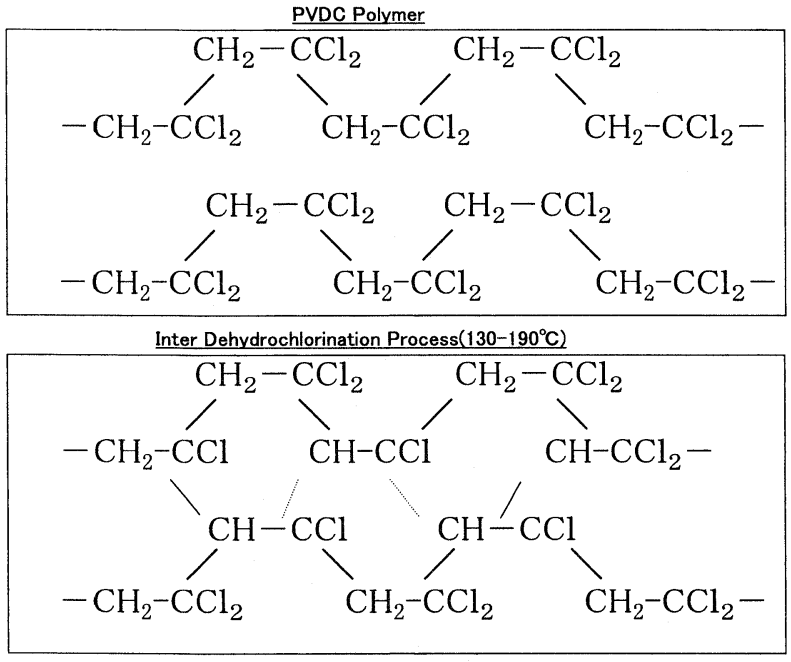

Initial Cyclization Process (Diels-Alder Reaction) $\left(250-350^{\circ} \mathrm{C}\right)$

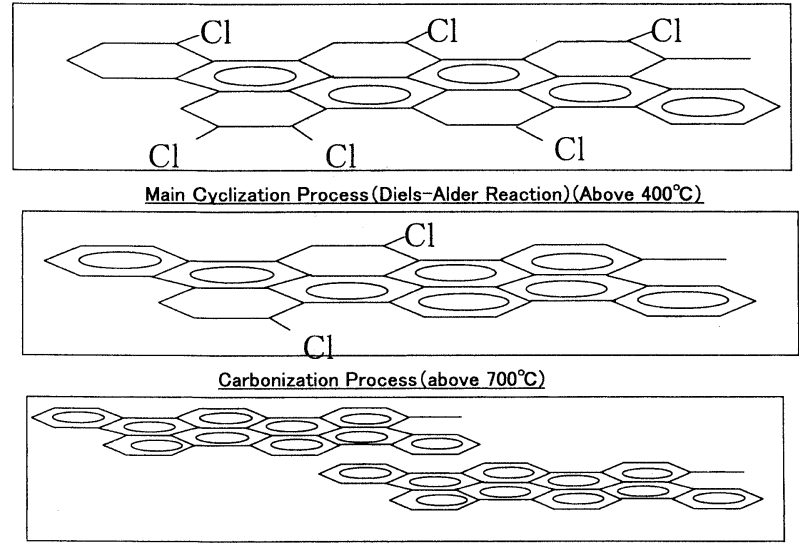

Fig.19 Process of pyrolysis mechanism on PVDC.

例えば，「新材料成形加工事典」1988 年版(株)産業調査会材料技 術センターに記載のプラスチックス成形技術やセラミック成形技 術を応用できる。セラミック編に記載されている, 鋳込み, 塑性, 射出, 加圧, テープ成形法が採用できる。

具体的には, 例えば, バインダーとPVDC 炭素前駆体または炭 素をコンパウンドにして, 射出成形, 押し出し成形圧縮成形によ り所定の成形体 (グリーン成形体) にして, 後に続く, 公知の賦活 工程，および/あるいは黒鉛化工程にてバインダーを焼尽させて,

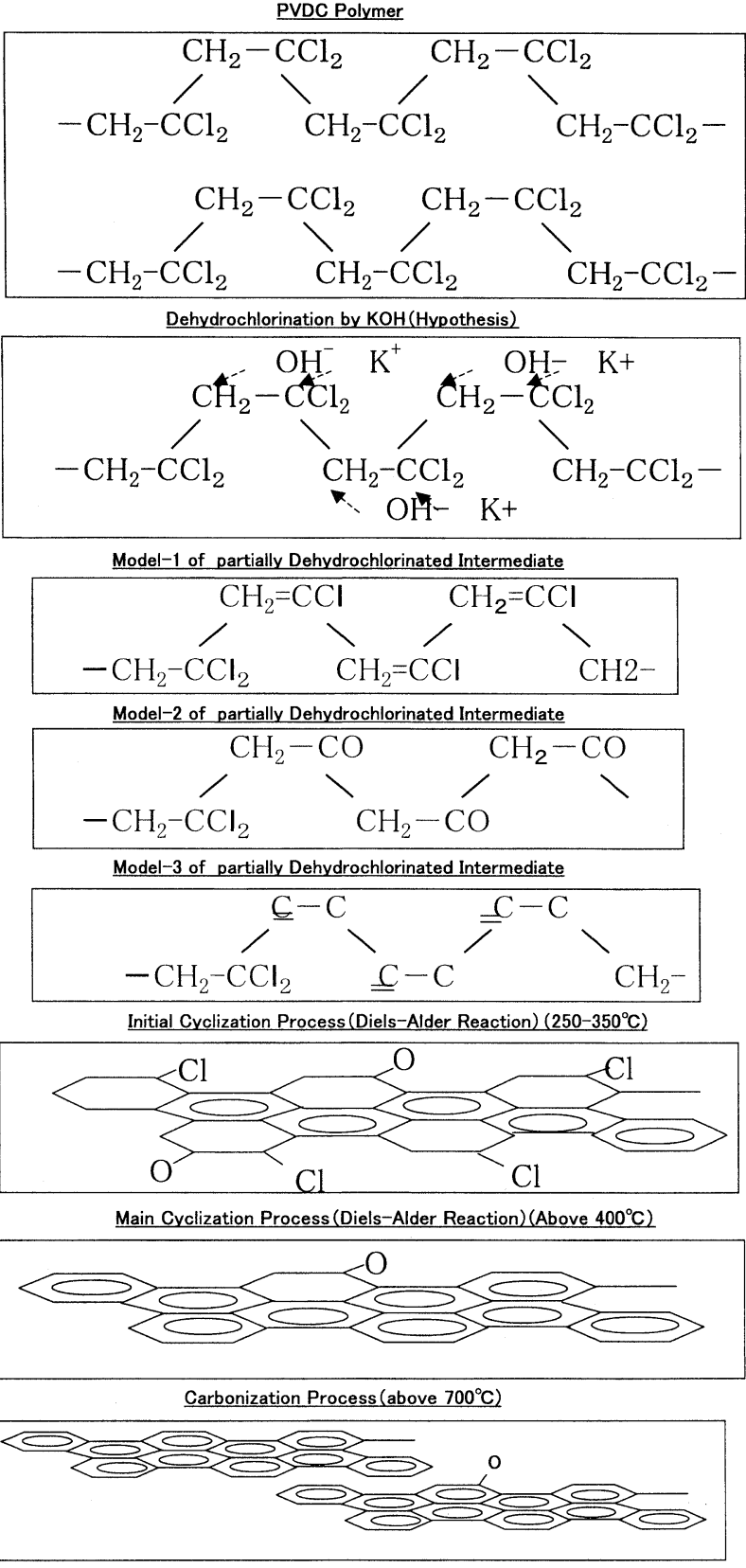

Fig.20 Process of alkaline teatment mechanism on PVDC.

希望する形状の炭素加工品や成型品の焼結体にできる。

また, 球状のナノサイズ炭素前駆体であるため, 公知の炭素加 工技術, 例えば, 焼結, 塗工は, 最も得意な適用加工技術である。

\section{2 .3 応用}

具体的用途として, 例えば「新・炭素材料入門」炭素材料学会 編集, 出版社(株)リアライズ社, 2000 年第 1 版第 3 刷や「炭素応用技 術」出版社(株)シーエムシー出版, 2001 年記載の公知の炭素製品に 応用できる。製鉄用途, 原子力用途, 航空宇宙用途, 電気機械用 途, 電子機械用途, 電池用途, 生物 - 生体用途, 土木 - 建築用途, 環境工学用途などに記載されている。例えば, 電極, 集電体, 電池 用炭素, 発熱体, 断熱材, 還元用炭素, 研廣剤, 摺動剤, 触媒担体, 酵素担体, バイオセンサー担体などが記載されている。

最近, 注目されている用途として, 電気二重層キャパシター電 
極用炭素, 水素やメタンガスやメタンハイドライドや天然ガスや LPG の吸蔵体炭素や水素吸蔵体炭素あるいは, ICチップやICメ モリー, ICカード, 光スイッチング・デバイス, DNA チップなど 幅広い用途が開発されている.また，ナノサイズ炭素前駆体また はこれを炭素化あるいは黒鉛化したナノサイズ炭素と金属, 金属 酸化物を担持させてなる炭素複合材として, 研磨剂用途で例えれ ば, ハードディスク基板やヘッド, 光ファイバー端面や光学部品 の精密研磨用に開発が進んでいる。これは液状ポリッシングや コーティングされた研磨フィルム用としても使用される。また， 電池電極用途では, 正, 負極活物質を担持させてなる岸素複合材 として使用できる。

PVDC 炭素前駆体は一次粒子が球状のナノサイズであること と粉体状, スラッジ状, 水分散体あるいは酸やアルカリ水分散体 で供給できることにより，各種加工技術が採用される点に優位性 が期待できる。

\subsubsection{PVDCの可能性}

PVDCは, 高度に分子デザインされた純度の高い合成ポリマー である。また，炭素前駆体は制御しやすい低温領域で，PVDCを アルカリ脱塩酸反応により得られる。引き続く高温炭素化反応 により得られる純度の高い炭素は, 具体応用に応じたデザイン された炭素材料, 例えば, 活性炭として, 今後の検討が待たれる。

具体的な検討項目に, 例えば, Table 4 に示すPVDC ポリマーの 原形態を保持できるドライ法やウエット法炭素前駆体の製法を 組み合わすことができる。工業的に製造されたPVDC製品や工 業的加工法を利用したりして, Table 5 に示す各種の炭素が試作 できる利点がある。

このようにして高度に分子デザインされた化学的純度の高い PVDC 炭素前駆体やPVDC 炭素のすみずみまで, 例えば, 水蒸気 や酸性ガス, 炭酸ガス, 一酸化炭素, 各種の酸化硫黄, 酸化窒素, 酸化ホウ素, 酸化リンで化学エッチングしたり, 炭素に隣接する 異種元素例えば, ホウ素, 窒素, 硫黄, リン, アルミニウム, ケイ素原 子などをドーピングすることにより特異的な構造をデザインした

Table 4 Process of PVDC nanocarbon precusor with its sustaining morphology.

\begin{tabular}{|c|c|}
\hline Process & Outline of Process \\
\hline Pyrolysis & $\begin{array}{c}\text { Dry process of dehydrochlorination by pyrolysisi below } \\
\text { PVDC's melting temperature in innert gas or vaccum }\end{array}$ \\
\hline Alkaline Treatment & Wet Process of dehydrochlorination by Alkaline in solution \\
\hline
\end{tabular}

ものはこれまでにはない特性が期待される。

化学的に, 物理的にすみずみまでデザインされた精緻な機能性 を賦与した機能性炭素材料として, 忘用をすみずみまで広げた分 野でデビューすることを期待したい。

\section{謝 辞}

本研究は平成 $12 \sim 15$ 年度文部科学省「産学官連携イノベーシ ヨン創出事業補助金 (独創的革新技術開発研究提案公募制度)」 により, 旭化成ケミカルズ(株にてて実施した。PVDC炭素のEDLC 電極への応用, VGCF 補強体の応用やEDLC電極用炭素構造電子 顕微鏡イメージのフラクタル理論や細孔径とイオン溶媒和径と のフィッティング理論に関する信州大学工学部 遠藤守信教授の 数々の助言に感謝する。

また, 炭素の硫酸吸着に関する九州大学先端物質化学研究所 持 田勲教授の広範な教唆に感謝する。群馬大学丁学部 大谷朝男教 授や愛知工業大学工学部 稻垣道夫教授には, ポリマーからの誘 導される炭素材料に関する化学的議論に感謝する。

最後に, 弊社の山口富男氏, 山内 裕氏それぞれに, TEM 観察, SEM 観察の協力に感謝する。

\section{文 献}

1) R. A. Wessling, Polyviniylidene Chloride, (1977) pp. 158-172, Gordon and Breach, NY.

2) 大谷杉郎, 日特開 昭和 53-108089, (公開日昭和 53 年 (1978) 9 月 20 日).

3) T. Takeda and M. Endo, TANSO 1999 [No.189] 179-187 [in Japanese] .

4) D. F. Quin and J. A. MacDonald, Carbon 30 (1992) 1097-1103.

5) M. A. Wojtowicz, B. L. Markowitz, W. W. Smith and M. A. Serio, Int. J. of The Soc. of Mat. Eng. For sources, 7 (2) (1999) 253-266.

6) Y. J. Kim, H. Ohta and M. Endo, Carbon 2003, Spain, Oviedo.

7) H. Tamai, M. Kouzu, M. Morita and H. Yasuda, Carbon 2003, Spain, Oviedo.

8) D. F. Quin and J. A. Holland, USP 5, 071, 820 (1991).

9) M. A. Wojtowicz, M. A. Serio and E. M. Suuberg, USP Application 2002/0020292 A1 (2002).

10) J. D. Carruthers, E. S. Sturn and J. Homan, Carbon 2003, Spain, Oviedo.

11) P. Pendlenton, B. Vincent and M. L. Hair, J. Coll. and Inter. Sci., 80 (12) (1981) 512-527.

Table 5 PVDC carbons.

\begin{tabular}{|l|c|c|c|}
\hline \multicolumn{1}{|c|}{$\begin{array}{c}\text { Polymerization Process/ } \\
\text { PVDC Polymer morphology }\end{array}$} & PVDC Fablicated Products & Carbon Precusors & Carbons \\
\hline $\begin{array}{l}\text { Suspension Polymerization/Porous } \\
\text { spharical particle (Dimameter100 } 200 \mu \mathrm{m} \phi)\end{array}$ & $\begin{array}{c}\text { Porous particle, Film or } \\
\text { Sheet, Filament, Foam }\end{array}$ & $\begin{array}{c}\text { Porous particle, Film or } \\
\text { Sheet, Filament, Foam }\end{array}$ & $\begin{array}{c}\text { Porous particle, } \\
\text { Film or Sheet, } \\
\text { Filament, Foam }\end{array}$ \\
\hline $\begin{array}{l}\text { Emulsion Polymerization/ } \\
\text { Nanoparticle (Diameter50 } \sim 150 \mathrm{~nm} \phi)\end{array}$ & $\begin{array}{c}\text { Aquaous latex, } \\
\text { organic solvent- suluble } \\
\text { resin }\end{array}$ & $\begin{array}{c}\text { Nanocarbon Precursor, } \\
\text { Ultra thin film Precursor }\end{array}$ & $\begin{array}{c}\text { Nanocarbon, } \\
\text { Ultra thin film } \\
\text { Carbon }\end{array}$ \\
\hline
\end{tabular}

